\title{
PENINGKATAN HASIL BELAJAR BIOLOGI MATERI EKOLOGI DENGAN MENGUNAKAN METODE KREATIF TIM PROYEK SISWA KELAS X IPA 8 SMAN 1 YOGYAKARTA
}

\author{
Menik Remen Lestari \\ SMA Negeri 1 Yogyakarta \\ menikremen@yahoo.co.id
}

\begin{abstract}
Abstrak: Penelitian ini dilatorbelakangi berdasarkan hasilobservasi dalam proses pembelajaran khususnya dalam materi lingkungan kelas X IPA8, sering kali siswa hanya memahami secara teoritispersoalan ekologi tidak dapat diaplikasikan dalam kehidupan sehari-hari. Permasalahan ini dapat diatasi dengan penelitian tindakan kelas dengan menggunakan metode kreatif tim proyek ekologi. Metode ini menekankan kegiatan belajar yang relatif berdurasi panjang, holistik interdisipliner, berpusat pada siswa dan terintegrasi dengan praktek dan isu-isu dunia nyata. Metode kreatif tim proyek ekologi diberikan dengan cara penugasan pembuatan miniseri drama bertema ekologi. Hasil Penelitian menunjukkan bahwa metode kreatif tim proyek ekologi berupa penugasan pembuatan miniseri drama bertema ekologi mampu meningkatkan hasil hasil belajar siswa di berbagai aspek kemampuan, baik kognitif, psikomotorik maupun afektif. Rata-rata nilai kognitif meningkat dari 83 menjadi 95. Hasil penilaian afektif rata-rata pada siklus I adalah 2.2 (kategori cukup) dan pada siklus II 3.8 (sangat baik). Sedangkan penilaian psikomotor juga terjadi peningkatan pada siklus I rata-ratanya adalah 79.2, sedangkan pada siklus II adalah 86.
\end{abstract}

Kata kunci: metode kreatif, tim proyek, hasil belajar biologi, materi ekologi

\section{IMPROVEMENT OF BIOLOGY LEARNING OUTCOMES IN ECOLOGY MATERIAL BY USING CREATIVE METHODS PROJECT TEAM FOR CLASS X IPA 8 STUDENTS OF SMAN 1 YOGYAKARTA}

\begin{abstract}
The research is based on the results of observations in the learning process, especially in the environment of class XIPA8. The students often only understand the theory of ecological problems yet cannot apply them in their daily lives. This issue can be addressed by conducting a class research using creative methods that will be done by groups of ecological project team. This method emphasizes learning activities that are relatively long duration, holistically interdisciplinary, student-centered and integrated with real-world practices and issues. This group will be given an assignment and guidance on how to make ecological-themed miniseries drama. The results show that the ecological project team's creative method in the form of an ecologythemed drama miniseries is able to improve student achievement outcomes in various aspects of abilities, both cognitive, psychomotor and affective. The average score increased from 83 to 95. The average affective assessment results in cycle I were 2.2 (adequate category) and in cycle II 3.8 (very good). While the psychomotor assessment also increased in the first cycle the average was 79.2, while in the second cycle was 86. Keyword: creative methods, project team, outcomes on biological, material ecoloigical
\end{abstract}

\section{PENDAHULUAN}

Banyak aspirasi berkembang dalam masyarakat dan para orang tua tentang masa depan anak-anak mereka, yang semuanya mengarah kepada kinerja guru (Oemar Hamalik, 2001: v). Ini menggambarkan bahwa pekerjaan guru tidak mudah, bahkan sangat rumit, termasuk juga masalah pembelajaran. Oleh karenanya guru dituntut untuk selalu aktif mengobservasi permasalahan di dalam kelas, kemudian menyelesaikannya dengan cara yang paling efektif. Salah satu hal yang dapat dilakukan guru agar pembelajaran berjalan lebih baik adalah dengan memperbaiki persiapan, pelaksanaan, dan evaluasi pembelajaran. Jadi guru memang seharusnya profesional dan total menjalankan perannya sebagai fasilitator dalam proses pembelajaran.
Berdasarkan hasil observasi menunjukkan bahwa dalam proses pembelajaran kelas $\mathrm{X}$ khususnya dalam materi ekologi kelas, sering kali siswa hanya memahami secara teoritis ekologi. Siswa juga tidak mampu memecahkan permasalahan lingkungan. Hal ini terlihat dari kurang aktifnya siswa dalam berdiskusi mengenai lingkungan, sehingga diskusi tidak berjalan secara efektif.

Berdasarkan hal tersebut perlunya adanya refleksi terhadap pembelajaran yang telah berlangsung karena inti dari proses pendidikan adalah kualitas pembelajaran. Prestasi belajar dan perubahan tingkah laku siswa (karakter siswa) adalah produk dari proses pembelajaran. Oleh karena itu guru dituntut memiliki kreativitas untuk meningkatkan kualitas pembelajaran. 
Seperti diketahui pembelajaran biologi tidak cukup mengkaji materi saja, tetapi siswa dikondisikan untuk berperilaku seperti saintis menggunakan metode ilmiah dan memiliki sikap ilmiah ketika menyelesaikan masalah. Depdiknas (2006) juga menjelaskan bahwa tujuan pembelajaran mata pelajaran biologi antara lain agar siswa memiliki kemampuan berpikir kritis, analitis, induktif dan deduktif dengan menghasilkan karya teknologi sederhana yang berkaitan dengan kebutuhan manusia. Memiliki sikap ilmiah, jujur, obyektif, ulet, kritis dan dapat bekerja sama dengan orang lain. Jika hal ini dipahami dan dilaksanakan secara ideal, pendidikan yang berkualitas akan menghasilkan generasi yang unggul.

Menyiasati kendala tersebut seorang guru dapat melakukan berbagai inovasi dalam proses pembelajaran, sehingga materi pembelajaran yang diajarkan kepada siswa mampu membekali siswa untuk menyiapkan dirinya menghadapi ujian nasional dengan kemampuan kognitif, namun tetap tidak melupakan tugas moral yang harus diembannya yaitu menjadikan peserta didik sebagai manusia bermoral yang mampu menyelesaikan permasalahan yang muncul dalam kehidupannya di masyarakat, sekarang maupun di masa yang akan datang. Hasilnya siswa memiliki kompetensi di berbagai aspek, baik kognitif, afektif maupun psikomotorik. Asumsi bahwa materi yang integratif dengan kehidupan nyata siswa akan membantu perkembangan moral dan etika siswa, tanpa siswa harus kehilangan motivasi dan minatnya dalam proses pembelajaran.

Metode proyek merupakan kegiatan pembelajaran, berupa pemberian suatu tugas kepada siswa yang harus diselesaikan dalam periode waktu tertentu. Tugas tersebut berupa suatu investigasi sejak dari perencanaan, pengumpulan data, pengorganisasian, pengolahan dan penyajian data. Penilaian proyek dapat digunakan untuk mengetahui pemahaman dan pengetahuan dalam bidang tertentu. (Depdiknas, 2003).

Metode kreatif tim yang dipadukan dengan metode proyek pada materi ekologi memberi peluang siswa bekerja secara otonom mengkonstruk belajar mereka sendiri dan puncaknya menghasilkan produk karya siswa bernilai dan realistik. Untuk selanjutnya metode ini kami sebut sebagai metode kreatif tim proyek. Metode ini menekankan kegiatan belajar yang relatif berdurasi panjang, holistik interdisipliner, berpusat pada siswa dan terintegrasi dengan praktek dan isu-isu dunia nyata.

Tujuan penelitian ini adalah mendeskripsikan penerapan metode pembelajaran kreatif tim proyek dan untuk meningkatkan hasil belajar biologi materi ekologi siswa SMA N 1 Yogyakarta.
Metode kreatif tim proyek dilaksanakan dalam proses belajar mengajar dengan memberikan proyek ekologi dalam sebuah tim yang berupa proyek pembuatan miniseri drama remaja bertema ekologi. Melalui pemberian tugas berupa proyek pembuatan miniseri drama remaja bertema ekologi ini peserta didik akan diajak berpikir bahwa belajar lingkungan adalah kegiatan yang menyenangkan dan akan memberikan pengalaman yang lebih menarik. Peserta didik akan lebih kreatif dalam menyelesaikan proyeknya, sehingga penguasaan materi mengenai ekologi akan lebih meningkat. Dalam penyelesaian proyek pembuatan miniseri drama remaja yang bertema ekologi peserta didik masing - masing mempunyai tanggung jawab dan peran tertentu dalam penyelesaian proyek.

Metode kreatif tim proyek berupa proyek pembuatan miniseri drama remaja bertema ekologi akan mampu meningkatkan pemahaman siswa terhadap bahan ajar, membekali siswa dengan keterampilan yang bermakna bagi kehidupannya serta menumbuhkan sikap positif terhadap lingkungan. Untuk meningkatkan nilai kognitif, afektif dan psikomotorik siswa, maka metode pembelajaran yang dipilih adalah metode pembelajaran yang dapat memaksimalkan keterlibatan siswa dalam proses belajar mengajar. Melalui metode kreatif tim dalam proyek ekologi melalui pemberian tugas pembuatan miniseri drama remaja bertema ekologi, peserta didik dapat memahami dirinya baik kekuatan maupun kelemahannya, memperdalam dan memperluas nilai-nilai materi yang dipelajari dan memperbaiki perilakunya dalam belajar.

Melalui metode pembelajaran kreatif tim proyek diharapkan dapat meningkatkan hasil belajar biologi materi ekologi siswa SMA N 1 Yogyakarta baik dari segi kognitif, afektif dan psikomotor.

\section{Tinjauan Metode Pembelajaran Kreatif Tim Proyek Ekologi}

Metode Pembelajaran Kreatif Tim Proyek Ekologi merupakan bagian dari pembelajaran berbasis proyek. Pembelajarn berbasis proyek (Project-Based Learning) adalah sebuah model atau pendekatan pembelajaran yang inovatif, yang menekankan belajar kontektual melalui kegiatankegiatan yang kompleks. Fokus pembelajaran terletak pada konsep-konsep dan prinsip-prinsip inti dari suatu disiplin studi, melibatkan siswa dalam investigasi pemecahan masalah dan kegiatan tugas-tugas bermakna yang lain, memberi kesempatan siswa bekerja secara otonom membentuk pengetahuan mereka sendiri dan mencapai puncaknya menghasilkan produk nyata (Kamdi, 2007). 
Langkah-langkah pembelajaran berbasis proyek menurut Maursund (dalam Made Wena, 2011) adalah sebagai berikut:

1. Perencanaan

Tahap ini sebagai langkah pertama kegiatan dimulai dengan pengajuan suatu masalah yang harus dipecahkan oleh siswa melalui suatu proyek. Masalah yang harus dipecahkan merupakan masalah yang nyata di lingkungan sekolah yang diperoleh oleh siswa. Siswa diberi kebebasan untuk menggunakan kemampuannya dalam menyelesaikan proyek.

2. Langkah permulaan

Tahap ini merupakan tahap penyusunan langkah penyelesaian proyek. Siswa dibimbing, diarahkan dan dimotivasi pada situasi belajar untuk memecahkan proyek secara mandiri.

3. Fase Lanjutan

Tahap ini merupakan tahap penyelesaian proyek menggunakan informasi, bahan, sumber dan metode yang dicari sendiri.

4. Fase Kulminasi

Merupakan fase puncak dari keseluruhan rangkaian yang dilakukan siswa pada pembelajaran berbasis proyek. Menyusun laporan, mengkomunikasikan hasil temuan dan pembahasan proyeknya melalui presentasi.

\section{Tinjauan Hasil Belajar}

Salah satu tugas pokok guru adalah mengevaluasi taraf keberhasilan dan pelaksanaan proses pembelajaran. Hasil belajar adalah kemampuan yang dimiliki atau dikuasai siswa setelah ia menerima pengalaman belajarnya (Sudjana, 2006:22) .

Menurut Benyamin Bloom, dkk (Vivien, 2005) membagi hasil belajar menjadi tiga ranah atau domain yaitu:

1. Ranah kognitif adalah kemampuan intelektual siswa. Ranah kognitif meliputi pengetahuan, pemahaman, aplikasi, analisis, sintesis dan evaluasi.

2. Ranah afektif adalah mengenai sikap, minat, emosi, nilai hidup dan apresiasi siswa.

3. Ranah psikomotor adalah reaksi fisis siswa seperti ditampakkan pada saat melakukan kegiatan. Ranah psikomotor meliputi persepsi, respon terbimbing, respon mekanistik dan respon kompleks dan organisasi.

\section{METODE PENELITIAN}

Penelitian ini dikelompokkan dalam Penelitian Tindakan Kelas (PTK). Pelaksanaan penelitian ini dilakukan dengan dengan model yang dikembangkan oleh Lewin yang ditafsirkan oleh Elliot (wiriatmadja, 2008). Pada umunya setiap siklus terdiri atas perencanaan, pelaksanaan, obeservasi dan refleksi.

Waktu pelaksanaan penelitian dilaksanakan selama 10 bulan mulai dari persiapan, pelaksanaan, sampai pelaporan. Pelaksanaan dilakukan pada Februari - November 2019. Penelitian ini bertempat di SMA N 1 Yogyakarta. Subyek Penelitian adalah siswa kelas X IPA 8 SMA N 1 Yogyakarta, yang berjumlah 28 siswa, terdiri dari 5 siswa laki-laki dan 23 siswa perempuan.

Prosedur penelitian tindakan kelas ini terdiri dari dua siklus.Proses dalam siklus itu meliputi empat komponen yaitu (1) perencanaan (planing), (2) tindakan (action), (3) observasi ( observising), (4) refleksi (reflektion). Data penelitian ini meliputi data hasil belajar berupa data penialaian kognitif, penilaian afektif dan penilaiaan psikomotor serta data proses belajar. Teknik pengumpulan data untuk penilaian kognitif dengan menggunakan test dengan instrumen lembar soal, untuk penilaian afektif dan psikomotor dengan observasi dengan instrumen lembar observasi Data yang dikumpulkan berbentuk hasil observasi dengan check list,kemudian dihitung skor masing-masing aspek. Skor dikonversi dengan tabel untuk melihat kategori yang dipakai. Untuk melihat hasil prestasi belajar dari daya serap kelas dilaksanakan post test. Validasi instrument ditempuh melalui fase validity dan critical reflection dari masingmasing kolaborator penelitian ini.

Analisis data dalam penelitian ini dilakukan dengan cara merefleksi hasil observasi terhadap proses pembelajaran reflektif yang dilaksanakan guru. Analisis data pada penelitian ini bersifat kualitatif dengan mengacu pada analisis Miles dan Huberman dalam Sugiyono (2010) yang dilakukan dalam 3 (tiga) komponen berurutan yakni reduksi data, penyajian data dan penarikan kesimpulan.

Adapun rangkaian kegiatan yang dilaksanakan pada kegiatan pembelajaran dengan menggunakan Metode Pembelajaran Kreatif TimProyek Ekologi adalah

1. Perencanaan

Dalam kegiatan perencanaan ini hal yang dilakukan adalah mengindentifikasi masalah yang terkait dengan pembelajaran biologi materi ekologi untuk mengembangkan metode tim kreatif proyek, mengidentifikasi alternatif pemecahan untuk mengatasi kendala dalam pembelajaran biologi materi ekologi, merancang kegiatan penerapan metode tim kreatif proyek dalam pembelajarn biologi materi ekologi, merancang strategi pembelajaran materi ekologi dengan 
penerapan metode tim kreatif proyek sehingga terjalin hubungan komplementer antara silabus dengan materi ajar dan menyiapkan perangkat pembelajaran, materi yang diajarkan adalah ekologi. Serta menyusun kelompok diskusi. Dalam hal ini secara siswa secara berkelompok akan memperoleh proyek dalam pembuatan mini seri drama bertema ekologi.

2. Pelaksanaan penelitian

Pada tahap pelaksanaan tindakan, dilakukan proses pembelajaran sesuai dengan desain tindakan yaitu penerapan metode pembelajaran materi ekologi pada Standar Kompetensi (SK) 4, yaitu menganalisis hubungan antara komponen ekosistem, perubahan materi dan energi serta peranan manusia dalam keseimbangan ekosistem dengan menggunakan metode kreatif tim proyek dengan penilaian produk, presentasi dan diskusi. Pembuatan miniseri drama bertema ekologi dilakukan siswa di rumah melalui penugasan atau proyek, sedangkan penilaian presentasi dan penilaian produk dan diskusi di sekolah. Setelah semua siswa melakukan presentasi mengenai miniseri drama yang dibuat, pembelajaran dilanjutkan dengan pembahasan, dan penarikan kesimpulan yang dilakukan oleh guru Bersama siswa.

3. Pengamatan

Untuk melihat proses belajar, mengamati selama proses belajar maka pengamat mengevaluasi dengan instrument yang sudah disiapkan meliputi instrument pengukuran ranah afektif meliputi respon positif pada guru, antusias siswa, partisipasi aktif siswa, komunikasi siswa dan rasa mampu dalam belajar. Instrument pengukuran ranah prikomotor meliputi penilaian produk miniseri drama. Selain itu untuk pengukuran ranah kognitif diadakan ulangan harian untuk mengetahui prosentase KKM.

4. Refleksi

Guru dan pengamat berdiskusi untuk melihat keberhasilan atau kegagalan yang terjadi setelah proses belajar mengajar dalam selang waktu tertentu. Hasil refleksi sebagai masukan guru dalam kolaborator untuk membuat perencanaan kembali untuk siklus berikutnya

Tindakan pada siklus II dan selanjutnya dilaksanakan berdasarkan temuan temuan hasil refleksi siklus I. Karena karakteristik materi hampir sama, maka digunakan metode pembelajaran yang sama dengan berbagai perbaikan.

\section{HASIL DAN PEMBAHASAN}

Prinsip utama metode kreatif tim proyek ekologi, adalah memberikan kemerdekaan kepada siswa mengaktualkan potensinya berjuang mencapai hasil terbaik. Peran guru dalam pembelajaran berbasis proyek adalah motivator, fasilitator, arranger konsultan dan partner ketika menyelesaikan proyek. Dalam hal ini proyek yang diberikan adalah pembuatan miniseri drama bertema ekologi, adapun kegiatan pembelajaran yang dilaksanakan adalah;

1. Pertemuan 1 (tahap perencanaan)

Kegiatan dimulai dengan pengajuan suatu masalah yang harus dipecahkan oleh siswa melalui proyek. Dalam hal ini adalah Ekologi. Kelompok 1. Ekosistem Sungai dan Pantai. Kelompok 2. Ekosistem Danau dan Ekosistem Sawah. 3. Ekosistem Hutan. Kemudian pemecahannya diserahkan kepada siswa sebagai proyek. Siswa diminta mencari sendiri informasi yang sesuai dengan bertanya atau mempelajari: buku, majalah, ensiklopedi atau internet. Selanjutnya siswa diberi tugas untuk melakukan pembuatan miniseri drama bertema ekologi.

2. Pertemuan 2 (tahap permulaan)

Pada tahap ini siswa diberi kebebasan untuk meyususun langkah penyelesaian proyek. Membuat jadwal, menentukan apa yang harus dikerjakan, menyampaikan ide cerita dan setting tempat. Siswa dibimbing, diarahkan dan dimotivasi pada situasi belajar untuk memecahkan proyek secara mandiri. Untuk penilaian, setiap kelompok diminta mempresentasikan rencana yang telah disusun dan rencana pembuatan miniseri drama secara bergantian dalam waktu 5 menit. Proyek yang dipresentasikan berupa draf ringkasan materi dan rancangan pembuatan miniseri drama yang sesuai masalah proyeknya, yaitu ekologi. Tahap ini bertujuan mencari masukan dari teman lain dan guru untuk memyempurnakan rancangan percobaan. Kegiatan ini mampu mengembangkan keberanian mengungkapkan pendapat dan explanation skill.

3. Kegiatan di luar sekolah

Tahap lanjutan adalah tahap penyelesaian proyek yang telah disusun, diluar jam pelajaran. Siswa diberi kebebasan menggunakan potensi yang dimilikinya, mengaplikasikan pengetahuan yang dicarinya sendiri dari berbagai sumber untuk memecahkan masalah proyeknya. Siswa melakukan pembuatan miniseri drama sesuai rancangan yang disusun. Selanjutnya hasilnya dituangkan dalam bentu rekaman. 
4. Tahap 3 (tahap kulminasi)

Tahap kulminasi merupakan puncak dari keseluruhan kegiatan yang dilakukan siswa pada pembelajaran berbasis proyek, yaitu menyusun laporan, mengkomunikasikan hasil rekaman miniseri drama dan penilaian produk. Pada saat presentasi diikuti dengan Tanya Jawab dan diskusi kelas. Selanjutnya guru mengevaluasi konsep yang diperoleh siswa menjelaskan konsep yang belum tercapai atau dikuasai siswa. Membahas temuan siswa dan membuat rangkuman. Pada akhir kegiatan guru mengevaluasi pelaksanaan presentasi dan diskusi kelas dengan memberikan tes hasil belajar.

Hasil refleksi awal diperoleh sebelum dilakukan tindakan yang berupa penerapan metode kreatif tim proyek ekologi dengan penilaian presentasi pembelajaran Biologi, khususnya materi lingkungan. Refleksi awal meliputi data penilaian dari tahun sebelumnya (tahun 2017/2018) dan efektifitas proses pembelajaran pada Kompetensi Dasar sebelumnya. Data mengenai pelaksanaan proses pembelajaran menggambarkan apersepsi yang diberikan guru di awal kegiatan pembelajaran kurang mampu membangkitkan motivasi dan minat siswa terhadap materi maupun kegiatan pembelajaran. Meskipun sudah diawali dengan diskusi kelompok, namun diskusi kelas berjalan kurang efektif. Respons siswa terhadap proses diskusi rendah (siswa kurang memahami materi diskusi dan malu malu dalam mengungkapkan pendapatnya). Siswa tampak masih takut berinteraksi dengan guru atau siswa lain. Nilai ulangan harian rendah (nilai rata-rata 62). Hanya $65 \%$ siswa yang mencapai KKM, sedangkan $35 \%$ siswa belum mencapai KKM. Tingkat ketercapaian KKM ulangan harian siswa pada refleksi awal seperti digambarkan pada Grafik 1.

\section{Ketercapaian KKM}

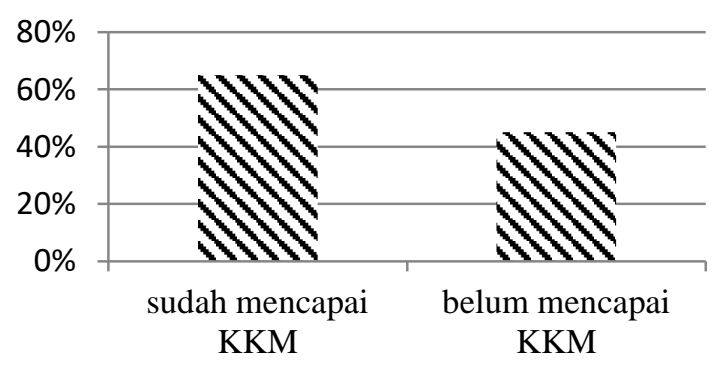

Gambar 1. Grafik tingkat ketercapaian KKM siswa (refleksi awal)

Pada siklus 1 kegiatan perencanaan dilakukan tindakan sebagai berikut: dilakukan siswa secara berkelompok sebagai tugas mandiri penugasan atau proyek berupa pembuatan miniseri drama bertema lingkungan, sedangkan penilaian presentasi dan pemutaran miniseri drama dan penilaian produk miniseri drama bertema lingkungan dilakukan di kelas. Setelah semua peserta didik melakukan presentasi, pembelajaran dilanjutkan dengan pembahasan dan penarikan kesimpulan yang dilakukan oleh guru bersama peserta didik.

Berdasarkan hasil pengamatan kolaborator selama pembelajaran pada siklus ini sebagian besar siswa terlihat antusias baik siswa baik selama pengerjaan tugas mandiri atau proyek, penilaian presentasi dan pemutaran miniseri drama, namun pada saat presentasi dan pemutaran film, siswa dalam pembuatan catatan- catatan masih perlu dilengkapi. Sehingga Keaktifan siswa dalam masih perlu dioptimalkan dalam membuat catatan-catatan untuk bahan diskusi, sehingga diskusi dapat berjalan lebih baik. Dari identifikasi masalah ini maka peneliti perlu memberi intervensi dalam proses belajar mengajar. Berikut ini adalah tahapan tahapan dalam penelitian tindakan kelas:

\section{Perencanaan}

Sebelum peneliti memberikan tindakan, terlebih dahulu peneliti mempersiapkan semua perangkat pembelajaran, seperti silabus dan RP Ekosistem, media pelajar maupun instrumen yang diperlukan dalam penelitian ini, baik yang digunakan guru peneliti, guru kolaboratif maupun siswa.

2. Pelaksanaan

Tindakan sebelum proses belajar mengajar, kelompok siswa yang akan tampil dalam presentasi dan pemutaran sudah ditunjuk oleh guru. Masing-masing kelompok melakukan presentas selama 5 menit, 45 menit untuk pemutaran film dan 15 menit untuk diskusi kelas. Siswa yang tidak presentasi membuat catatan materi yang perlu didiskusikan. Guru membagi siswa menjadi 3 kelompok belajar, sebagai media pembelajaran digunakan LCD dan perangkatnya.

3. Pengamatan

Hasil dari tindakan yang dilaksanakan, menunjukkan bahwa pengamatan yang dilakukan oleh peneliti terhadap 3 kelompok yang sedang melaksanakan proses belajar mengajar dengan metode kreatif tim proyek dapat dilihat pada tabel $1-4$.

\section{Refleksi}

Hasil pengamatan yang terlihat, walau telah tercapai keberhasilan perubahan tingkah laku dalam proses belajar mengajar, tetapi 
keberhasilannya masih dapat ditingkatkan, hal ini di tunjukkan dari pengamatan kondisi pembelajaran yang termasuk kategori baik dan ketercapaian KKM sebesar 78,57\%., Kenyataan ini dapat dimengerti, karena adanya kendala dalam proses belajar mengajar yaitu terlihat dari kemauan belajar siswa masih baik dan segi partisipasi dalam kelompok maupun klasikal masil kategori baik.

Hasil tindakan siklus I dan II berupa data penilaian kemampuan kognitif siswa yang diperoleh dari nilai ulangan harian, data kemampuan psikomotorik siswa yang diperoleh dari penilaian produk siswa serta data kemampuan afektif yang diperoleh dari penilaian presentasi dan diskusi kelas. Secara rinci data tindakan siklus I dan II disajikan pada Tabel 1 hingga Tabel 3.

Tabel 1. Penilaian kemampuan kognitif siswa

\begin{tabular}{|c|c|c|c|}
\hline \multirow{2}{*}{ No } & \multirow{2}{*}{ Aspek pencapaian } & \multicolumn{2}{|c|}{ siklus } \\
\hline & & I & II \\
\hline 1 & $\begin{array}{l}\text { Rata-rata nilai ulangan } \\
\text { harian }\end{array}$ & $83,43 \%$ & $95,88 \%$ \\
\hline 2 & $\begin{array}{l}\text { Presentase } \\
\text { KKM }\end{array}$ & $85,45 \%$ & $97,50 \%$ \\
\hline
\end{tabular}

Tabel 2. Data Pengamatan Kelompok Siswa (Ranah Afektif) Siklus 1 dan 2

\begin{tabular}{clccccc}
\hline \multirow{2}{*}{ No } & \multirow{2}{*}{ Aspek yang diamati } & \multicolumn{2}{c}{ Siklus I } & \multicolumn{2}{c}{ Siklus II } \\
\cline { 3 - 6 } & & Skor & Nilai & Skor & Nilai \\
\hline 1 & Antusias siswa & 2,5 & B & 3,9 & SB \\
2 & Kefokusan siswa & 1.9 & $\mathrm{C}$ & 3,9 & SB \\
3 & Keaktifan siswa dalam bertanya & 2.2 & $\mathrm{C}$ & 3,6 & SB \\
4 & Keaktifan siswa dalam menjawab pertanyaan guru & 2,6 & $\mathrm{~B}$ & 3,9 & SB \\
5 & Inisiatif siswa dalam member jawaban siswa yang lain & 1.9 & $\mathrm{C}$ & 3,6 & SB \\
\hline \multicolumn{2}{c}{ Rata-rata } & 2,2 & $\mathrm{C}$ & 3,8 & SB \\
\hline
\end{tabular}

Tabel 3. Nilai Psikomotorik siswa (Nilai produk) hasil tindakan siklus I dan II

\begin{tabular}{clcccc}
\hline \multirow{2}{*}{ No } & \multirow{2}{*}{ Aspek yang dinilai } & \multicolumn{2}{c}{ Siklus 1 } & \multicolumn{2}{c}{ Siklus 2 } \\
\cline { 3 - 6 } & & Rata-rata & Nilai KKM & Rata-rata & Nilai KKM \\
\hline 1 & Kualitas tampilan & 78 & 75 & 85 & 75 \\
2 & Ketepatan tema & 80 & 75 & 85 & 75 \\
3 & Durasi/waktu & 80 & 75 & 90 & 75 \\
4 & skenario & 78 & 75 & 80 & 75 \\
5 & Pemeran & 80 & 75 & 90 & 75 \\
\hline & Rata-rata & 79.2 & 75 & 86 & 75 \\
& Ketercapaian KKM $(\%)$ & 100 & 75 & 100 & 75 \\
\hline
\end{tabular}

Hasil observasi oleh kolaborator menunjukkan pada siklus I masih menunjukkan kekompakan antar anggota kelompok masih perlu ditingkatkan, beberapa siswa kurang berpartisipasi aktif dalam kegiatan presentasi, bahwa pembagian tugas dan kerjasama antar siswa kurang optimal. Dari hasil refleksi ini digunakan untuk melakukan tindakan pada siklus ke 2 yaitu pada siklus II pemberian proyek berupa pembuatan miniseri drama, pada siklus tindakan ditambah dengan pemberian LKS sehingga nilai afektifnya meningkat.

Data yang diperoleh dari hasil refleksi tindakan siklus I menunjukkan bahwa metode kreatif tim proyek ekologi berupa penugasan pembuatan miniseri drama bertema ekologi mampu meningkatkan hasil prestasi belajar siswa di berbagai aspek kemampuan, baik kognitif, psikomotorik maupun afektif. Rata-rata nilai meningkat dari 83 menjadi 95 , yang berarti telah melampaui nilai KKM yang telah ditetapkan yaitu 75 , dari hasil penilaian afektif rata-rata pada siklus I adalah 2.2 (kategori cukup) dan pada siklus II 3.8 (sangat baik). Sedangkan penilaian psikomotor juga terjadi peningkatan pada siklus I rata-ratanya adalah 79.2, sedangkan pada siklus II adalah 86 . Pemantauan peningkatan kualitas pembelajaran dari ranah psikomotor pada siswa yang dilakukan pada saat observasi proses belajar mengajar menunjukkan terjadinya peningkatan dalam pembelajarn biologi secara kualitatif yang terlihat dari penilaian produk.

Berdasarkan hasil refleksi menujukkan bahwa pada siklus II terjadi peningkatan psikomotor, nilai kognitif karena tugas proyek yang diberikan yang berupa pembuatan miniseri drama sangat bermanfaat bagi kehidupan siswa secara langsung. Peningkatan nilai koginitif dan psikomotor ini berkaitan pula dengan peningkatan pada nilai afektif siswa. 
Dari data yang diperoleh terlihat adanya peningkatan penilaian ranah afektif, kognitif maupun psikomotor yang diperoleh dari hasil observasi. Adapun peningkatan penilaian afektif tersebut adalah siklus $\mathrm{I}=2,2$ (cukup) dan siklus II $=3,8$ (sangat baik). Pemantauan peningkatan kualitas pembelajaran dari segi afekti yaitu pada siswa yang dilakukan pada saat observasi proses belajar mengajar menujukkan peningkatn siswa dalam pembelajaran biologi secara kualitatif yang dilhat dari dari aspek antusias siswa dalam mengikuti proses belajar mengajar, kefokusan siswa, keaktifan siswa dalam mengajukan pertanyaan, keaktifan dalam menjawab pertanyaan guru dan inisiatif siswa dalam member jawaban dari pernyataan siswa yang lain.

Hasil wawancara dengan siswa terungkap bahwa siswa sangat senang dengan model pembelajaran berbasis proyek ini, karena selain mampu menyampaikan pesan moral tentang kepedulian terhadap lingkungan, mereka juga dapat berkreasi dalam pembuatan miniseri drama yang sesuai dengan jiwa remaja mereka. Antusiasme siswa dalam berkreasi inilah yang secara berkelanjutan mampu meningkatkan motivasi siswa dan selanjutnya meningkatkan prestasi belajar.

Hasil tindakan siklus II berupa data penilaian prestasi belajar siswa, baik aspek kognitif, psikomotorik dan afektif, setelah dilakukan tindakan siklus II berupa penerapan metode ekologi kreatif tim proyek dengan penugasan pembuatan miniseri drama. Perbedaan dengan tindakan siklus I pada tema miniseri drama yaitu dari materi Lingkungan .

Berdasarkan hasil wawancara dengan siswa bahwa produk miniseri drama bertema ekologi yang dihasilkan dirasakan lebih bermanfaat bagi siswa, sehingga siswa merasa bangga dengan hasil karya sendiri. Kebanggaan ini akan meningkatkan motivasi dan secara berkelanjutan meningkatkan minat belajar. Lebih penting dari peningkatan nilai kognitif adalah guru yang sebelumnya hanya mampu mengungkap aspek kemampuan kognitif siswa, setelah dilakukan tindakan berupa penerapan metode kreatif tim proyek ekologi berupa miniseri drama ekologi dengan penilaian presentasi dan produk, kini guru telah mampu mengungkap aspek kemampuan psikomotorik serta aspek afektif siswa. Adapun antara siklus I dan siklus II terlihat terjadi peningkatan prestasi belajar siswa dari semua aspek kemampuan siswa. Perubahan nyata yang tampak antara kondisi awal, setelah tindakan siklus I dan tindakan siklus II adalah peningkatan ketercapaian KKM. Dari $55 \%$ pada kondisi awal, menjadi $85,45 \%$ setelah tindakan siklus I dan menjadi 97,50 $\%$ setelah dilakukan tindakan siklus II.
Intervensi metode kreatif tim proyek ekologi memberikan pengaruh positif terhadap pembelajaran biologi. Hal ini disebabkan karena metode pembelajaran tim kreatif proyek ekologi banyak melibatkan siswa dalam kegiatan pemecahan masalah dan tugas-tugas bermakna lainnya, memberi peluang siswa bekerja secara otonom mengkonstruksi belajar mereka sendiri dan puncaknya menghasilkan produk karya siswa bernilai dan realistik. Siswa tampak belajar tanpa terbebani oleh muatan-muatan konsep yang dirasakan berat jika dipelajari dengan kegiatan pembelajaran konvensional. Metode kreatif tim proyek ekologi adalah penggerak yang unggul untuk membantu siswa belajar melakukan tugastugas otentik dan multidisipliner, menggunakan sumber-sumber yang terbatas secara efektif dan bekerja dengan lain. Secara kuantitatif suasana pembelajaran biologi dirasakan kondusif dibandingkan sebelum dilakukan tindakan. Hal ini dirasakan baik oleh siswa maupun oleh guru yang dipantau dari observasi proses belajar mengajar dan mendukung terciptanya iklim belajar yang lebih baik di lingkungan sekolah serta memberikan motivasi pada rekan guru lain untuk lebih terbuka dengan siswa, kreatif dalam menciptakan kegiatan pembelajaran, lebih bersahabat dengan siswa tanpa meninggalkan wibawa guru. Di dalam kerja kelompok suatu proyek, kekuatan individu dan cara belajar yang diacu memperkuat kerja tim sebagai suatu keseluruhan. Dampak yang ditimbulkan dari metode kreatif tim proyek ekologi dalam pembelajaran biologi terhadap pencapaian hasil belajar siswa (ranah kognitif).

\section{SIMPULAN}

Berdasarkan uraian dalam pembahasan dapat disimpulkan sebagai berikut:

1. Penerapan metode pembelajaran kreatif tim proyek dalam pembelajaran biologi materi ekologi ini terdiri dari 4 tahap yaitu pertemuan 1 (tahap perencanaan), pertemuan 2 (tahap permulaan), kegiatan di luar sekolah, dan tahap 3 (tahap kulninasi).

2. Penerapan metode pembelajaran kreatif tim proyek ekologi menyebabkan terjadi peningkatan hasil belajar siswa dari semua aspek kemampuan siswa. baik kognitif, psikomotorik maupun afektif. Rata-rata nilai meningkat dari 83menjadi 95, dari hasil penilaian afektif rata-rata pada siklus I adalah 2.2 (kategori cukup) dan pada siklus II 3.8 (sangat baik). Sedangkan penilaian psikomotor juga terjadi peningkatan pada siklus I rataratanya adalah 79.2, sedangkan pada siklus II adalah 86. 


\section{DAFTAR PUSTAKA}

Anonim. 2004. Penerapan Konsep Zero Waste Dalam Pengolahan Sampah Perkotaan. http://www.geocities.com/persampah an/0waste.doc. di akses tanggal 10 Februari 2012

Anonim. 2006. Kurikulum Tingkat Satuan Pendidikan Standar Kompetensi dan Kompetensi Dasar Mata Pelajaran Biologi. Badan Standar Nasional Pendidikan

Arsyad, Azhar. 2007. Media Pembelajaran. Jakarta: Raja Garfindo Persada

Dikdasmen. 2003. Model Sistem Penyampaian Kurikulum. Jakarta: Depdiknas.

Hamalik, Oemar.2001. Perencanaan Pengajaran Berdasarkan Pendekatan Sistem. Jakarta: Penerbit Bumi Aksara

Kamdi, W. 2007. Model Pembelajaran Projoct Based Learning. Semarang: UNS Press

Marpaung. 2001. Teknik Komunikasi dan Presentasi yang Efektif. Jakarta: Airlangga
Mashur, Muslich. 2011. Melaksanakan PTK itu Mudah. Jakarta: Bumi Aksara

Rusman. 2012. Model-Model Pembelajaran. Jakarta: PT. Raya Grafindo Persada

Soemarwoto, Otto. 2001. Atur Diri Sendiri Paradigma Baru Pengelolaan Lingkungan Hidup. Yogyakarta: Gajah Mada University Press.

Sudana, Nyoman Degeng. 2004. Teori Pembelajaran. Jawa Timur: UM Press

Sudjana, Nana. 2005. Penilaian Hasil Belajar Mengajar. Bandung: Remaja Rosdakarya

Sunaryo. 1998. Evaluasi Hasil Pembelajaran. Jakarta: Departemen Pendidikan dan Kebudayaan

Supriyanto. 2006. Pembelajaran Berbasis Proyek (Project Based learning) untuk Meningkatkan Academic Skill Siswa MI Miftahul Ulum 02 Jember. Jakarta. 